\title{
The $\beta$-Secretase Enzyme BACE in Health and Alzheimer's Disease: Regulation, Cell Biology, Function, and Therapeutic Potential
}

\author{
Robert Vassar, ${ }^{1}$ Dora M. Kovacs, ${ }^{2}$ Riqiang Yan, ${ }^{3}$ and Philip C. Wong ${ }^{4}$ \\ ${ }^{1}$ Department of Cell and Molecular Biology, Northwestern University, Chicago, Illinois 60611, ${ }^{2}$ MassGeneral Institute for Neurodegenerative Disease, \\ Massachusetts General Hospital and Department of Neurology, Harvard Medical School, Charlestown, Massachusetts 02129, ${ }^{3}$ Department of Neuroscience, \\ Cleveland Clinic, Lerner Research Institute, Cleveland, Ohio 44195, and ${ }^{4}$ Department of Pathology, Johns Hopkins University School of Medicine, \\ Baltimore, Maryland 21231
}

The $\beta$-amyloid $(\mathrm{A} \beta)$ peptide is the major constituent of amyloid plaques in Alzheimer's disease (AD) brain and is likely to play a central role in the pathogenesis of this devastating neurodegenerative disorder. The $\beta$-secretase, $\beta$-site amyloid precursor protein cleaving enzyme (BACE1; also called Asp2, memapsin 2), is the enzyme responsible for initiating A $\beta$ generation. Thus, BACE is a prime drug target for the therapeutic inhibition of $A \beta$ production in $\mathrm{AD}$. Since its discovery 10 years ago, much has been learned about $\mathrm{BACE}$. This review summarizes BACE properties, describes BACE translation dysregulation in AD, and discusses BACE physiological functions in sodium current, synaptic transmission, myelination, and schizophrenia. The therapeutic potential of BACE will also be considered. This is a summary of topics covered at a symposium held at the 39th annual meeting of the Society for Neuroscience and is not meant to be a comprehensive review of BACE.

BACE: the $\boldsymbol{\beta}$-secretase in Alzheimer's disease

Although the etiology of Alzheimer's disease (AD) is not completely understood, the study of disease genes that cause AD has revealed important clues about the pathogenesis of this disorder. Familial AD (FAD) cases are caused by autosomal dominant mutations in the genes for amyloid precursor protein (APP) and the presenilins (PS1 and PS2) (Sisodia and St George-Hyslop, 2002). These mutations increase production of the 42-aa-long, fibrillogenic form of $\mathrm{A} \beta\left(\mathrm{A} \beta_{42}\right)$, relative to $\mathrm{A} \beta_{40}$. In addition, patients with APP gene duplications or individuals with Down's syndrome (trisomy 21), who have increased dosage of the APP gene (located on chromosome 21), develop early-onset AD and overproduce $A \beta_{42}$ (Hardy, 2006). These findings, along with a large body of evidence from other sources (Selkoe, 2008), strongly suggest that $\mathrm{A} \beta_{42}$ plays a central, early role in $\mathrm{AD}$ pathogenesis. Thus, therapeutic strategies to lower cerebral $A \beta_{42}$ levels are expected to be beneficial for the treatment or prevention of $\mathrm{AD}$.

$\mathrm{A} \beta$ is produced through the endoproteolysis of APP, a large type 1 transmembrane protein. Cleavage of APP by two proteases, the $\beta$ - and $\gamma$-secretases, is required to liberate $\mathrm{A} \beta$ from APP (Tanzi and Bertram, 2005). The $\beta$-secretase cuts APP first to generate the $\mathrm{N}$ terminus of $\mathrm{A} \beta$, thus producing a membrane bound C-terminal fragment called C99. Then, $\gamma$-secretase cleaves C99 to release the mature A $\beta$ peptide. A third protease, $\alpha$-secretase, cuts APP within the $\mathrm{A} \beta$ domain, thus precluding $\mathrm{A} \beta$ formation.

Received July 28, 2009; revised Aug. 27, 2009; accepted Aug. 28, 2009.

Correspondence should be addressed to Robert Vassar at the above address. E-mail:r-vassar@northwestern.edu. D01:10.1523/JNEUROSCI.3657-09.2009

Copyright $\odot 2009$ Society for Neuroscience $\quad$ 0270-6474/09/2912787-08\$15.00/0 $\gamma$-secretase processing produces several $\mathrm{A} \beta$ peptides with heterogeneous $C$ termini ranging from 38 to 43 residues in length. However, $\beta$-secretase cleavage occurs precisely at Asp +1 and Glu +11 of $A \beta$, indicating that $\beta$-secretase is a site-specific protease. Importantly, therapeutic inhibition of $\beta$-secretase would decrease production of all forms of $\mathrm{A} \beta$, including the pathogenic $\mathrm{A} \beta_{42}$.

The identity of the $\beta$-secretase had long been sought because of its prime status as a drug target for AD. Before the enzyme's discovery, the properties of $\beta$-secretase activity in cells and tissues had been extensively characterized, the knowledge of which was instrumental in its identification. In 1999, five groups reported the molecular cloning of the $\beta$-secretase, variously naming the enzyme BACE (Vassar et al., 1999), $\beta$-secretase (Sinha et al., 1999), Asp2 (Hussain et al., 1999; Yan et al., 1999), or memapsin 2 (Lin et al., 2000) (here, $\beta$-secretase will be referred to primarily as BACE). The groups used very different isolation methods (i.e., expression cloning, protein purification, genomics), yet all identified the same enzyme and concurred that it possessed all the known characteristics of $\beta$-secretase (Fig. 1) (Cole and Vassar, 2008).

BACE is a novel 501 aa type 1 transmembrane aspartic protease related to the pepsin and retroviral aspartic protease families. BACE activity has a low $\mathrm{pH}$ optimum, and the enzyme is predominantly localized in acidic intracellular compartments (e.g., endosomes, trans-Golgi) with its active site in the lumen of the vesicles. The highest expression levels of BACE are found in neurons of the brain, as expected for $\beta$-secretase. Importantly, BACE cDNA transfection or BACE antisense oligonucleotide treatment of APP-overexpressing cells increases or decreases production of $\mathrm{A} \beta$ and $\beta$-secretase-cleaved APP fragments, respec- 
tively. In addition, the specific activity of recombinant BACE on wild-type and mutant APP substrates is consistent with $\beta$-secretase. For example, BACE cleaves APP with the Swedish FAD-causing mutation (APPswe) 10- to 100-fold more efficiently than wild-type APP, as expected for $\beta$-secretase. Soon after BACE was discovered, a homolog was identified, BACE2. BACE1 and BACE2 share 64\% amino acid sequence similarity, which raised the possibility that BACE2 was also a $\beta$-secretase. However, BACE2 is expressed at low levels in neurons of the brain and it does not have the same cleavage activity on APP as $\beta$-secretase, thus indicating that it was a poor $\beta$-secretase candidate.

To unequivocally exclude BACE2 and validate BACE1 as the $\beta$-secretase in vivo, $B A C E 1^{-/-}$mice were generated by several groups (Cai et al., 2001; Luo et al., 2001; Roberds et al., 2001). Initial reports indicated that $B A C E 1^{-1-}$ mice were viable and fertile, suggesting that therapeutic inhibition of BACE1 might produce few mechanism-based side effects. However, recent studies have shown that $B A C E 1^{-/-}$mice are not completely normal (discussed below). It is not yet known whether therapeutic inhibition of BACE1 would produce these abnormalities in humans and cause untoward side effects.

Importantly, $\mathrm{A} \beta$ generation, amyloid pathology, electrophysiological dysfunction, and cognitive deficits are abrogated when $B A C E 1^{-/-}$mice are bred to APP transgenics (Luo et al., 2001, 2003; Ohno et al., 2004, 2007; Laird et al., 2005). BACE1 ${ }^{-/-}$mice are devoid of cerebral $A \beta$ production, demonstrating that BACE1 is the major if not only $\beta$-secretase enzyme in the brain. This notion is further supported by reports of lentiviral delivery of BACE1 RNA interference (RNAi) that can attenuate A $\beta$ amyloidosis and cognitive deficits in APP transgenic mice (Laird et al., 2005; Singer et al., 2005). In addition, the rescue of memory deficits in $B A C E 1^{-/-} ; A P P$ bigenic mice suggests that therapeutic BACE1 inhibition should improve $A \beta$-dependent cognitive impairment in humans with $\mathrm{AD}$. Together, the BACE1 characterization and validation studies have unequivocally demonstrated that BACE1 is the authentic $\beta$-secretase in the brain and that it is a promising therapeutic target for lowering cerebral $\mathrm{A} \beta$ levels in $\mathrm{AD}$.

\section{BACE cell biology}

BACE1, like all the other aspartic proteases, is initially synthesized as a zymogen (containing a short prodomain) in the endoplasmic reticulum (ER). If HEK-293 cells are pretreated with brefeldin A to block transport of membrane proteins from the ER to the Golgi compartment and then the treated cells are transfected with a BACE1 expression construct, immature BACE1 will cleave APP to produce significantly more C99 than in control transfected cells (Yan et al., 2001). This observation is consistent with the finding that the prodomain in BACE1 is less rigid than the other aspartic proteases and fails to block the entrance of APP into the BACE1 active cleft (Shi et al., 2001; Hong et al., 2002). Within the lumen of the ER, BACE1 is subjected to simple glycosylation on four Asn residues (Haniu et al., 2000) and transient acetylation on seven Arg residues (Costantini et al., 2007). Further addition of complex carbohydrates and removal of the BACE1 prodomain by furin convertases occur in the Golgi com- partment (Bennett et al., 2000; Capell et al., 2000; Benjannet et al., 2001; Creemers et al., 2001). The maturation of BACE1 increases the catalytic activity of the enzyme by at least twofold over that of immature BACE1. In addition, the low $\mathrm{pH}$ of the late Golgi/TGN and early endosome compartments, where mature BACE1 is largely localized, enhances BACE1 activity.

BACE1 is phosphorylated on $\operatorname{Ser}^{498}$, and this phosphorylation together with a C-terminal dileucine motif regulates BACE1 recycling between the cell surface and endosomal compartments (Huse et al., 2000; Walter et al., 2001). BACE1 is also S-palmitoylated on four Cys residues located at the junction of the transmembrane and cytosolic domains (Benjannet et al., 2001; Vetrivel et al., 2009), and this modification facilitates BACE1 partitioning into lipid rafts. Increased targeting of BACE1 to the lipid raft had been suggested to enhance $\beta$-secretase processing of APP (Tun et al., 2002; Cordy et al., 2003). However, a recent study has reported that non-raft-localized palmitoylation-deficient BACE1 is equally active in APP processing and $\mathrm{A} \beta$ secretion as raftassociated palmitoylated BACE1 (Vetrivel et al., 2009). Although BACE1 can process APP in both raft and nonraft environments, a membrane-anchored version of a BACE1 transition-state inhibitor produced by linkage to a sterol moiety appeared more potent as a result of targeting to lipid rafts (Rajendran et al., 2008).

Intracellular localization of BACE1 can be altered by various regulatory factors. Increased cellular expression of reticulon/ Nogo proteins, identified as BACE1 interacting proteins (He et al., 2004; Murayama et al., 2006), significantly increases retention of BACE1 within the ER, which has a suboptimal neutral $\mathrm{pH}$ environment for BACE1 activity (Shi et al., 2009). This increased ER retention causes reduced levels of BACE1-cleaved C99 in cortical regions of transgenic mice expressing RTN3 (Tg-RTN3). In addition, increased interaction between BACE1 and RTN proteins spatially obstructs access of BACE1 to APP and reduces $\mathrm{A} \beta$ generation. When Tg-RTN3 mice are bred with doubletransgenic mice expressing APPswe and PS1 $1 \mathrm{E} 9$ (Borchelt et al., 1997), both C99 and A $\beta$ levels are reduced and amyloid deposition is significantly diminished in triple transgenic mice overexpressing APPswe, PS1 $1 \mathrm{E} 9$, and RTN3 in the same neurons. It has also been shown that the levels of monomeric RTN3, a neuronally expressed reticulon protein, are significantly reduced in brains of AD patients, and this RTN3 reduction may potentially increase BACE1 activity (Hu et al., 2007).

While increased localization of BACE1 within the ER reduces generation of $\mathrm{A} \beta$, intracellular trafficking of BACE1 to the more acidic endosomes clearly enhances $\mathrm{A} \beta$ production. Golgi- 
localized $\gamma$-ear-containing ARF-binding (GGA) proteins interact with the BACE1 C-terminal DXXLL motif via a VHL domain and regulate trafficking of $\mathrm{BACE} 1$ between the late Golgi and early endosomes (He et al., 2002, 2003; von Arnim et al., 2004). Depletion of GGA proteins by RNAi or disruption of phosphorylation of BACE1 on Ser ${ }^{498}$ increases accumulation of BACE1 in early endosomes, an acidic environment that favors BACE1 cleavage of APP (He et al., 2005; Wahle et al., 2005; Tesco et al., 2007). Importantly, GGA3 is a caspase 3 substrate and is degraded during neuronal apoptosis. In the brains of $\mathrm{AD}$ patients, in which neuronal apoptosis may occur, the levels of GGA3 are significantly decreased (Tesco et al., 2007). Reduced GGA3 levels not only increase localization of BACE1 to early endosomes but also stabilize BACE1 by preventing its trafficking to lysosomes where it is degraded. Hence, therapeutic elevation of cerebral levels of both RTN3 and GGA3 might be beneficial for AD patients.

One of the unique structural features of BACE1 among aspartic proteases is the presence of a type I transmembrane domain $\left(\mathrm{Val}^{461}-\mathrm{Val}^{477}\right)$. This membrane domain contributes to the enriched retention of BACE1 within the late Golgi and TGN compartments, and removal of this transmembrane domain creates a soluble form of BACE1 that is rapidly secreted into the extracellular medium (Yan et al., 2001). A fraction of BACE1 expressed in cells is normally shed between $\mathrm{Ala}^{429}$ and $\mathrm{Val}^{430}$, possibly by an ADAM-like sheddase (Hussain et al., 2003). The secreted BACE1 ectodomain presumably acts like other aspartic proteases such as cathepsin D or cathepsin E, both of which efficiently process peptide substrates containing the $\beta$-secretase cleavage site in vitro, but not in vivo. Hence, increased shedding of BACE1 likely represents an alternative strategy to reduce BACE1 processing of APP, because soluble BACE1 fails to form an optimal spatial interaction with APP in cells (Yan et al., 2001). Moreover, elevated ADAM activity may not only increase shedding of BACE1, but may also increase cleavage of APP at the $\alpha$-secretase site and thereby reduce formation of $\mathrm{A} \beta$.

\section{BACE1 elevation in AD}

Interestingly, recent studies have determined that levels of BACE1 protein and activity are elevated approximately twofold in AD brain (Fukumoto et al., 2002; Yang et al., 2003; Li et al., 2004), suggesting the possibility that the BACE1 increase might initiate or accelerate $\mathrm{AD}$ pathogenesis. Indeed, $\mathrm{FAD}$ caused by the APP Swedish mutation that enhances APP cleavage by BACE1 implies that elevated BACE1 activity can lead to AD. Other results suggest that BACE1 is a stress-response protein: levels of the enzyme are increased by oxidative stress (Tamagno et al., 2002), hypoxia (Zhang et al., 2007), ischemia (Wen et al., 2004), apoptosis (Tesco et al., 2007), and traumatic brain injury (Blasko et al., 2004). Since impaired glucose metabolism is a hallmark of AD brain (de Leon et al., 1983), Velliquette and colleagues explored whether this type of cellular stress might elevate BACE1 levels in the brain. Indeed, treatment of APP transgenic mice with drugs that disrupt energy metabolism caused cerebral levels of BACE1 and $\mathrm{A} \beta$ to increase approximately twofold (Velliquette et al., 2005), similar to the elevation observed in AD. This BACE1 increase was not derived from elevated BACE1 gene expression, since BACE1 mRNA levels did not rise following treatment.

Using cell culture systems, O'Connor and colleagues determined that the posttranscriptional BACE1 increase following energy deprivation was the result of increased efficiency of BACE1 mRNA translation via phosphorylation of the translation initiation factor eIF2 $\alpha$ (O'Connor et al., 2008). BACE1 mRNA has a long GC-rich 5' untranslated (UTR) region with three upstream open reading frames ( $\mathrm{uORFs}$ ) that repress translation under normal unstressed conditions when eIF $2 \alpha$ is unphosphorylated (Lammich et al., 2004). However, different cellular stresses activate at least four kinases that phosphorylate $\operatorname{IF} 2 \alpha$, which in turn increases scan-through of the uORFs in the BACE1 mRNA $5^{\prime}$ UTR and reinitiation of translation at the BACE1 ORF. The beststudied example of this type of translational control is regulation of yeast GCN4 mRNA translation by amino acid deprivation (Schröder and Kaufman, 2006). Other stresses also activate the eIF2 $\alpha$ phosphorylation pathway, such as the ER stress/unfolded protein response (UPR), which induces phosphorylation of the eIF2 $\alpha$ kinase called PERK. Glucose deprivation induces UPR and activates PERK, which appears to be the eIF $2 \alpha$ kinase responsible for eIF $2 \alpha$ phosphorylation and the BACE1 increase under this cellular stress condition. Treatment of APP transgenic mice with inhibitors of energy metabolism causes an increase in the levels of phosphorylated eIF2 $\alpha$, BACE1, A $\beta$, and amyloid plaques (O'Connor et al., 2008). Moreover, elevated levels of phosphorylated eIF2 $\alpha$ positively correlate with increased BACE1 and amyloid levels in postmortem human AD brain samples. Interestingly, APP transgenic mice show elevated levels of phosphorylated eIF $2 \alpha$ and BACE1 without glucose deprivation, suggesting that amyloid itself might induce cellular stress and eIF $2 \alpha$ phosphorylation. These results are consistent with the hypothesis that age-related impairment of energy metabolism early in the disease may induce eIF $2 \alpha$ phosphorylation and increase BACE1 levels to initiate $\mathrm{AD}$, but once a critical threshold of amyloid pathology is reached, the reaction becomes self-sustaining and $\mathrm{AD}$ progression is accelerated. Further work in the area of stress-induced BACE1 elevation should shed additional light on the role of eIF $2 \alpha$ phosphorylation in $\mathrm{AD}$ pathogenesis.

\section{BACE substrates}

In addition to APP, BACE1 has other substrates (Fig. 2), and identification of these substrates is useful not only for evaluation of potential mechanism-based toxicity arising from inhibition of BACE1 but also for designing potent and selective BACE1 inhibitors. In addition, the existence of multiple BACE1 substrates suggests a variety of BACE1 physiological functions. The inability of soluble BACE1 to efficiently process full-length APP suggests that BACE1 substrates are likely to be membrane-bound proteins. Indeed, all reported BACE1 substrates are transmembrane proteins, such as Golgi-localized membrane-bound $\alpha 2,6$-sialyltransferase (Kitazume et al., 2001), P-selectin glycoprotein ligand-1 (PSLG-1) (Lichtenthaler et al., 2003), the APP homolog proteins APLP1 and APLP2 (Eggert et al., 2004; Li and Südhof, 2004; Pastorino et al., 2004), low-density lipoprotein receptor-related protein (LRP) (von Arnim et al., 2005), the voltage-gated sodium channel $\left(\mathrm{Na}_{\mathrm{v}} 1\right) \beta 2$ subunit $\left(\mathrm{Na}_{\mathrm{v}} \beta_{2}\right)$ (Kim et al., 2005; Wong et al., 2005), neuregulin-1 (NRG1) (Hu et al., 2006; Willem et al., 2006), and neuregulin-3 (NRG3) (Hu et al., 2008). Abrogating BACE1 cleavage of NRG1, and perhaps NRG3, causes reduced myelin sheath thickness of axons of both peripheral sciatic nerves (Hu et al., 2006; Willem et al., 2006) and central optic nerves (Hu et al., 2006). Moreover, this abrogated cleavage of NRG1 also impairs remyelination of injured sciatic nerves $(\mathrm{Hu}$ et al., 2008). The cleavage site of BACE1 in neuregulin has been mapped to $\mathrm{Phe}^{237}-\mathrm{Met}^{238}$, the location of which is surprisingly only 10 aa from the membrane. The other identified substrate cleavage sites are approximately 17 (PSLG-1), 20 (APP-A $\beta$ Glu +11 ), or 30 $(\mathrm{APP}-\mathrm{A} \beta \mathrm{Asp}+1)$ residues from the membrane. Shortening or twisting APP in the region between the membrane and the BACE1 cleavage site disrupts BACE1 processing (Qahwash et al., 2004), 


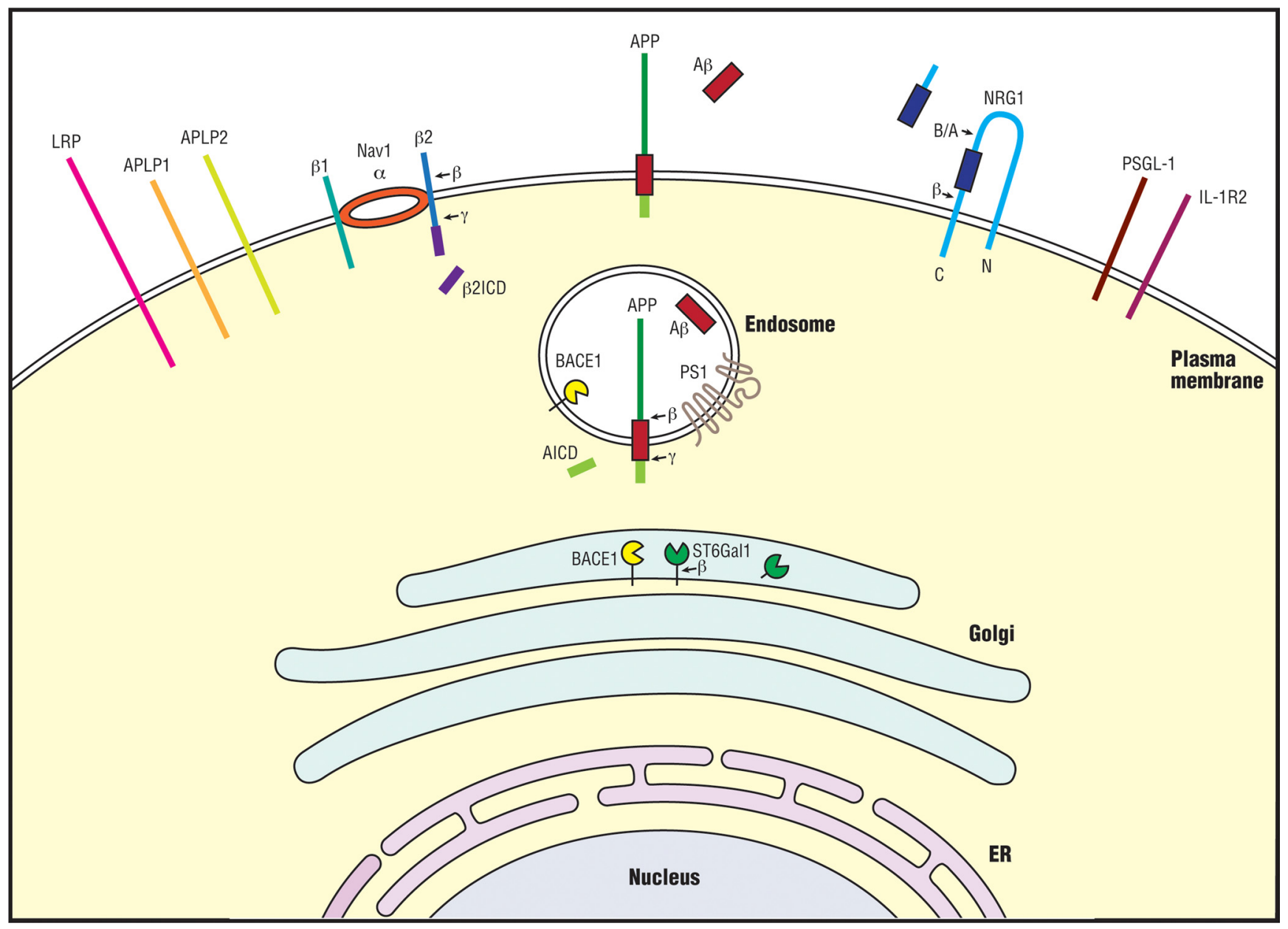

Figure 2. BACE1 substrate processing in the cell. The major known BACE1 substrates are depicted as colored stick figures in the membrane: APP, APLP2, APLP2, IL-1R2, LRP, Na $\beta 2$ 2, NRG1, PSGL-1, and ST6Gal1. Cleavage of APP by BACE1 $(\leftarrow \beta)$ in the endosome is shown as a typical example of BACE1 substrate processing. Most, if not all, BACE1 substrates are also processed by $\gamma$-secretase $(\leftarrow \gamma)$, which in the case of APP releases A $\beta$ (red rectangle) for secretion. APP intracellular domain (AICD) is also released and acts as a cotransactivator of gene transcription in the nucleus, similar to the function of $\mathrm{Na}_{\mathrm{v}} \beta 2$ intracellular domain $(\beta 2 \mathrm{ICD})$ in $\mathrm{Na}_{\mathrm{v}} 1 \alpha$ gene expression. Type III NRG1 is cleaved by BACE1 at a site adjacent to the transmembrane domain ( $\beta \rightarrow$ ). The second cut may occur by either BACE1 or ADAM cleavage $(B / A \rightarrow)$ and will release an EGF-like domain (blue rectangle) that signals through ErbB4 in adjacent glial cells to regulate axon myelination. Type I NRG1 and NRG3 are also cleavable by BACE1. ST6Gal1 is processed by BACE1 in the trans-Golgi network. PS1, Presenilin-1 component of $\gamma$-secretase; $N$ and C, N terminus and C terminus of NRG1, respectively.

suggesting that the secondary structure of BACE1 substrates affects enzyme-substrate interaction. Similarly, binding of the BACE1 cleavage site in APP by an antibody also blocks BACE1 processing of APP (Chang et al., 2007).

\section{Regulation of voltage-gated sodium channel levels by BACE and $\gamma$-secretase}

Of the known substrates of BACE1 in addition to APP, $\mathrm{Na}_{\mathrm{v}} \beta_{2}$ appears to be a major BACE1 substrate in the CNS. BACE1 overexpression in mice induces neurochemical changes, alterations in exploratory behavior, and, with high BACE1 expression levels, neurological deficits (Harrison et al., 2003; Rockenstein et al., 2005). Opposite behavioral changes are observed in BACE1-null mice (Harrison et al., 2003). The changes in behavioral phenotypes are consistent with altered neuronal membrane excitability in these mice and may be the result of $\mathrm{Na}_{\mathrm{v}} \beta_{2}$ dysregulation.

Voltage-gated sodium channels $\left(\mathrm{Na}_{\mathrm{v}} 1 \mathrm{~s}\right)$ almost exclusively carry out the rising phase of action potentials in axonal initial segments, nodes of Ranvier, and neuromuscular junctions. $\mathrm{Na}_{\mathrm{v}} 1 \mathrm{~s}$ consist of a single pore-forming $\alpha$-subunit and one or two $\beta$ accessory subunits (Catterall, 2000). The $\beta 1-4$ subunits are type I single-transmembrane proteins with extracellular Ig domains and short intracellular C-terminal domains that modify the localization, cell surface expression and inactivation of the $\alpha$-subunits by direct interaction (Catterall, 2000; Isom, 2001; Yu et al., 2003). The $\mathrm{Na}_{\mathrm{v}} 1 \beta 2$ subunit, $\mathrm{Na}_{\mathrm{v}} \beta_{2}$, plays an important role in the regulation of sodium channel density and function in neurons in vivo and is possibly required for normal action potential generation and neuronal excitability (Chen et al., 2002; LopezSantiago et al., 2006). $\mathrm{Na}_{\mathrm{v}} 1 \alpha$ and $\beta 2$ subunits assemble by disulfide linkage, resulting in the appearance of sodium channels at the cell surface (Schmidt and Catterall, 1986; Catterall, 2000). Studies of $\mathrm{Na}_{v} \beta_{2}$-null mice show that the absence of $\mathrm{Na}_{\mathrm{v}} \beta_{2}$ leads to a decrease of sodium current density (Chen et al., 2002; LopezSantiago et al., 2006). Mutations in both $\mathrm{Na}_{\mathrm{v}} 1 \alpha$ and $\beta$ subunits have been linked to inherited epilepsy (Wallace et al., 1998; Claes et al., 2001; Audenaert et al., 2003; Meisler and Kearney, 2005; Scheffer et al., 2007; Holland et al., 2008; Misra et al., 2008). Abnormal sodium channel activity also induces tremor, ataxia, spasticity, dystonia, altered pain sensitivity, and cognitive and behavior deficits in mouse and human (Catterall et al., 2008). Interestingly, epileptic symptoms can be induced by both decreased and increased $\mathrm{Na}_{\mathrm{v}} 1$ function, so any imbalance in sodium 
channel function may ultimately lead to seizures (Waxman, 2007; Catterall et al., 2008).

The $\beta 2$ subunit of the $\mathrm{Na}_{\mathrm{v}} 1$ undergoes processing via either the $\alpha$ - and $\gamma$-secretase or $\beta$ - and $\gamma$-secretase cleavage pathways in vitro and in vivo (Kim et al., 2005; Wong et al., 2005). Of the four $\mathrm{Na}_{\mathrm{v}} 1 \beta$ subunits, only $\mathrm{Na}_{\mathrm{v}} \beta_{2}$ appears to be a BACE1 substrate in the cerebrum (Wong et al., 2005). Increased BACE1- and $\gamma$-secretase-mediated processing of $\mathrm{Na}_{\mathrm{v}} \beta_{2}$ regulates $\alpha$-subunit $\mathrm{Na}_{\mathrm{v}} 1.1$ mRNA and protein levels in neuronal cells, BACE1 transgenic mice, and AD patients with elevated levels of BACE1 in brain (Kim et al., 2007). Specifically, BACE1 cleavage of $\mathrm{Na}_{\mathrm{v}} 1 \beta 2$ results in a membrane-anchored C-terminal fragment that is further processed by $\gamma$-secretase. This releases a short intracellular fragment of $\mathrm{Na}_{\mathrm{v}} 1 \beta 2$, which enters the nucleus and increases $\mathrm{Na}_{\mathrm{v}} 1.1$ mRNA levels presumably by acting as a transcriptional coactivator. While BACE1 overexpression results in increased intracellular $\mathrm{Na}_{\mathrm{v}} 1.1$ mRNA and protein levels, $\mathrm{Na}_{\mathrm{v}} 1.1$ accumulates intracellularly. This explains reduced cell surface expression of sodium channels and reduced sodium current densities in BACE1-expressing neuroblastoma cells and BACE1 adult hippocampal neurons (Kim et al., 2007). An important question is the physiological contribution of BACE1 cleavage of the $\mathrm{Na}_{\mathrm{v}} \beta_{2}$ to sodium channel expression in cell-based models and in vivo. Experiments in $B A C E 1^{-/-}$mice are needed to answer this question. Indeed, it appears that lack of BACE1 activity in $B A C E 1^{-/-}$mice modifies $\mathrm{Na}_{\mathrm{v}} 1.1$ expression. Similarly, PS1 FAD mutations alter sodium channel expression in a cell-based model. Together, all data are consistent with a function of BACE1 and $\gamma$-secretase in modulating $\mathrm{Na}_{\mathrm{v}} 1$ levels and activity in both physiological conditions and $\mathrm{AD}$ models.

Given the essential role of $\mathrm{Na}_{\mathrm{v}} 1$ in action potential generation and propagation, changes in BACE1 and $\gamma$-secretase activities may interfere with normal brain function. Since BACE1 activity and levels are significantly increased in $\mathrm{AD}$ brains, consequent dysfunction in $\mathrm{Na}_{\mathrm{v}} 1$ activity may also contribute to AD pathogenesis or epileptic symptoms observed in a subset of $\mathrm{AD}$ patients.

\section{BACE as a therapeutic target for Alzheimer's disease}

As discussed above, BACE1 participates in the proteolytic processing of NRG1 (Hu et al., 2006; Willem et al., 2006), a ligand for members of the ErbB family of receptor-tyrosine kinases. This signaling pathway has numerous roles in the CNS, including synapse formation, plasticity, neuronal migration, myelination of central and peripheral axons, and the regulation of neurotransmitter expression and function (Falls, 2003; Michailov et al., 2004). In addition to these physiological roles, NRG1 is one of the first genes that have been linked to an increased risk of schizophrenia (Stefansson et al., 2002). Moreover, a number of mouse models with various NRG1 deletions exhibit multiple behaviors relevant to schizophrenia (Gerlai et al., 2000; Stefansson et al., 2002). Given the strong genetic and functional links of NRG1 to schizophrenia (Stefansson et al., 2002; Law et al., 2006), that young $B A C E 1^{-/-}$mice have mild deficits in a task that assesses spatial memory (Ohno et al., 2004), and roles for BACE1 in the biology of NRG1 (Hu et al., 2006; Willem et al., 2006), investigators have tested the idea that perturbations in NRG1 signaling in $B A C E 1$-null mice may result in the behavioral phenotypes reminiscent of some of the features of schizophrenia. Indeed, Savonenko and coworkers showed that $B A C E 1^{-1-}$ mice exhibit a sensorimotor-gating deficiency, behavioral signs of glutamatergic hypofunction, and other typical endophenotypes of schizophrenia (Savonenko et al., 2008). Moreover, postsynaptic density protein
95 (PSD95)-associated ErbB4 and spine densities are reduced in $B A C E 1$-null mice, indicating that altered BACE1-dependent NRG1/ErbB4 signaling leads to schizophrenic-like phenotypes (Savonenko et al., 2008).

Importantly, Wang and coworkers showed that presynaptic function is reduced in BACE1-null mice, and that mossy fiber long-term potentiation (LTP) was absent in these animals (Wang et al., 2008). These workers also showed that the specific deficit in mossy fiber LTP was upstream of cAMP signaling and could be rescued by transiently elevating extracellular $\mathrm{Ca}^{2+}$ concentration, indicating that BACE1 may play a critical role in regulating presynaptic function, especially activity-dependent strengthening of presynaptic release, at mossy fiber synapses (Wang et al., 2008). Together, these observations indicate that the balance of various BACE1-dependent processes appears to be important for both normal and abnormal performance, and future studies should be alert to potential mechanism-based side effects that may occur with strong inhibition of BACE1 designed to attenuate $\mathrm{A} \beta$ amyloidosis in $\mathrm{AD}$.

Because of potential untoward side effects associated with strong inhibition or reduction of BACE1, investigators have tested whether a moderate decrease in BACE1 activity would provide benefits in the CNS while limiting mechanism-based toxicities. Laird and coworkers showed a significant reduction of $\mathrm{A} \beta$ deposition in brains of 12 month-old APPswe;PS1DE9; $B A C E 1^{+/-}$mice compared with that of APPswe;PS1DE9;BACE1 $1^{+/+}$ mice; however, no significant differences were observed in brains of 20-month-old APPswe;PS1DE9;BACE $1^{+/-}$animals (Laird et al., 2005). It is unclear why the older mice in this study did not show reduced amyloidosis. In a similar study, McConlogue and colleagues reported significantly reduced $\mathrm{A} \beta$ burden in the brains of 13- and 18-month-old PDAPP;BACE1 ${ }^{+/-}$mice (McConlogue et al., 2007). Although the results of the two studies appear to have some differences, together the data suggest the exciting possibility that only partial inhibition of BACE1 may be required to reduce $\mathrm{A} \beta$ burden.

Because the processing of APP to generate $\mathrm{A} \beta$ requires both $\gamma$-secretase and BACE1, and that modest reduction of $\gamma$-secretase provides benefit to the brain without adverse side effects ( $\mathrm{Li}$ et al., 2007 ), it is possible that reductions of both enzymes would provide additive protection against $\mathrm{A} \beta$ amyloidosis. To assess the value of this novel anti-amyloid combination therapy, Chow and coworkers took advantage of availability of a mouse model lacking one allele each of Aph-1a and BACE1 that possesses $\sim 30 \%$ and $50 \%$ of $\gamma$-secretase and BACE1, respectively, to model such a therapeutic strategy in $A P P$ swe; $P S 1 \triangle E 9$ mice. Importantly, these investigators showed that the genetic reductions of both $A p h-1 a$ and $B A C E 1$ additively attenuate the amyloid burden and ameliorate cognitive deficits occurring in APPswe;PS1 $\triangle E 9$ mice (Chow et al., 2009). Moreover, Aph-1 $1 a^{+/-} ; B A C E 1^{+/-}$mice exhibit normal life span compared with littermate controls, and they do not show any overt pathological or behavioral abnormalities (Chow et al., 2009). Together, these observations identify a novel combination therapy of moderately targeting both BACE1 and $\gamma$-secretase as an effective and safe therapeutic strategy for AD.

\section{Concluding remarks}

Since the discovery of BACE1 a decade ago, our knowledge about this enzyme has increased significantly. Based on the crystal structure of BACE1 (Hong et al., 2002) and medicinal chemistry studies, significant progress has been made toward the development of small molecule inhibitors capable of penetrating the blood-brain barrier and having sufficient potency to inhibit $\mathrm{A} \beta$ 
generation in vivo [for review, see Ghosh et al. (2008) and Silvestri (2009)]. However, despite promising news of BACE1 inhibitor development, BACE1 therapeutics for routine $\mathrm{AD}$ treatment are not yet available. Although BACE1 small molecule inhibitor medicinal chemistry and pharmacokinetics have proven challenging, the recent entry of at least one BACE1 inhibitor into clinical trial is an encouraging advance toward BACE1 therapeutic inhibition for the treatment of AD. Given recent data hinting at important physiological roles for BACE1, careful titration of BACE1 drug dosage may be necessary to minimize mechanism-based side effects. Moreover, the diverse substrates of BACE1 imply a larger potential role for BACE1 in other diseases in addition to $\mathrm{AD}$, such as schizophrenia. Finally, advancing our understanding of the roles of BACE1 in health and disease will facilitate the development of novel therapies for AD and may shed light on the etiology of this devastating disease and other disorders of the nervous system.

\section{References}

Audenaert D, Claes L, Ceulemans B, Löfgren A, Van Broeckhoven C, De Jonghe $\mathrm{P}$ (2003) A deletion in SCN1B is associated with febrile seizures and early-onset absence epilepsy. Neurology 61:854-856.

Benjannet S, Elagoz A, Wickham L, Mamarbachi M, Munzer JS, Basak A, Lazure C, Cromlish JA, Sisodia S, Checler F, Chrétien M, Seidah NG (2001) Post-translational processing of $\beta$-secretase ( $\beta$-amyloid-converting enzyme) and its ectodomain shedding. The pro- and transmembrane/cytosolic domains affect its cellular activity and amyloid- $\beta$ production. J Biol Chem 276:10879-10887.

Bennett BD, Denis P, Haniu M, Teplow DB, Kahn S, Louis JC, Citron M, Vassar R (2000) A furin-like convertase mediates propeptide cleavage of BACE, the Alzheimer's beta-secretase. J Biol Chem 275:37712-37717.

Blasko I, Beer R, Bigl M, Apelt J, Franz G, Rudzki D, Ransmayr G, Kampfl A, Schliebs R (2004) Experimental traumatic brain injury in rats stimulates the expression, production and activity of Alzheimer's disease betasecretase (BACE-1). J Neural Transm 111:523-536.

Borchelt DR, Ratovitski T, van Lare J, Lee MK, Gonzales V, Jenkins NA, Copeland NG, Price DL, Sisodia SS (1997) Accelerated amyloid deposition in the brains of transgenic mice coexpressing mutant presenilin 1 and amyloid precursor proteins. Neuron 19:939-945.

Cai H, Wang Y, McCarthy D, Wen H, Borchelt DR, Price DL, Wong PC (2001) BACE1 is the major beta-secretase for generation of Abeta peptides by neurons. Nat Neurosci 4:233-234.

Capell A, Steiner H, Willem M, Kaiser H, Meyer C, Walter J, Lammich S, Multhaup G, Haass C (2000) Maturation and pro-peptide cleavage of $\beta$-secretase. J Biol Chem 275:30849-30854.

Catterall WA (2000) From ionic currents to molecular mechanisms: the structure and function of voltage-gated sodium channels. Neuron 26:13-25.

Catterall WA, Dib-Hajj S, Meisler MH, Pietrobon D (2008) Inherited neuronal ion channelopathies: new windows on complex neurological diseases. J Neurosci 28:11768-11777.

Chang WP, Downs D, Huang XP, Da H, Fung KM, Tang J (2007) Amyloidbeta reduction by memapsin 2 (beta-secretase) immunization. FASEB J 21:3184-3196.

Chen C, Bharucha V, Chen Y, Westenbroek RE, Brown A, Malhotra JD, Jones D, Avery C, Gillespie PJ 3rd, Kazen-Gillespie KA, Kazarinova-Noyes K, Shrager P, Saunders TL, Macdonald RL, Ransom BR, Scheuer T, Catterall WA, Isom LL (2002) Reduced sodium channel density, altered voltage dependence of inactivation, and increased susceptibility to seizures in mice lacking sodium channel beta 2-subunits. Proc Natl Acad Sci U S A 99:17072-17077.

Chow VW, Savonenko AV, Melnikova T, Kim H, Price DL, Li T, Wong PC (2009) Modeling an anti-amyloid combination therapy for Alzheimer's Disease. Soc Neurosci Abstr 35:527.7.

Claes L, Del-Favero J, Ceulemans B, Lagae L, Van Broeckhoven C, De Jonghe P (2001) De novo mutations in the sodium-channel gene SCN1A cause severe myoclonic epilepsy of infancy. Am J Hum Genet 68:1327-1332.

Cole SL, Vassar R (2008) The role of amyloid precursor protein processing by BACE1, the beta-secretase, in Alzheimer disease pathophysiology. J Biol Chem 283:29621-29625.
Cordy JM, Hussain I, Dingwall C, Hooper NM, Turner AJ (2003) Exclusively targeting beta-secretase to lipid rafts by GPI-anchor addition upregulates beta-site processing of the amyloid precursor protein. Proc Natl Acad Sci U S A 100:11735-11740.

Costantini C, Ko MH, Jonas MC, Puglielli L (2007) A reversible form of lysine acetylation in the ER and Golgi lumen controls the molecular stabilization of BACE1. Biochem J 407:383-395.

Creemers JW, Ines Dominguez D, Plets E, Serneels L, Taylor NA, Multhaup G, Craessaerts K, Annaert W, De Strooper B (2001) Processing of $\beta$-secretase by furin and other members of the proprotein convertase family. J Biol Chem 276:4211-4217.

de Leon MJ, Ferris SH, George AE, Christman DR, Fowler JS, Gentes C, Reisberg B, Gee B, Emmerich M, Yonekura Y, Brodie J, Kricheff II, Wolf AP (1983) Positron emission tomographic studies of aging and Alzheimer disease. AJNR Am J Neuroradiol 4:568-571.

Eggert S, Paliga K, Soba P, Evin G, Masters CL, Weidemann A, Beyreuther K (2004) The proteolytic processing of the amyloid precursor protein gene family members APLP-1 and APLP-2 involves alpha-, beta-, gamma-, and epsilon-like cleavages: modulation of APLP-1 processing by n-glycosylation. J Biol Chem 279:18146-18156.

Falls DL (2003) Neuregulins: functions, forms, and signaling strategies. Exp Cell Res 284:14-30.

Fukumoto H, Cheung BS, Hyman BT, Irizarry MC (2002) Beta-secretase protein and activity are increased in the neocortex in Alzheimer disease. Arch Neurol 59:1381-1389.

Gerlai R, Pisacane P, Erickson S (2000) Heregulin, but not ErbB2 or ErbB3, heterozygous mutant mice exhibit hyperactivity in multiple behavioral tasks. Behav Brain Res 109:219-227.

Ghosh AK, Kumaragurubaran N, Hong L, Koelsh G, Tang J (2008) Memap$\sin 2$ (beta-secretase) inhibitors: drug development. Curr Alzheimer Res 5:121-131.

Haniu M, Denis P, Young Y, Mendiaz EA, Fuller J, Hui JO, Bennett BD, Kahn S, Ross S, Burgess T, Katta V, Rogers G, Vassar R, Citron M (2000) Characterization of Alzheimer's beta-secretase protein BACE. A pepsin family member with unusual properties. J Biol Chem 275:21099-21106.

Hardy J (2006) Amyloid double trouble. Nat Genet 38:11-12.

Harrison SM, Harper AJ, Hawkins J, Duddy G, Grau E, Pugh PL, Winter PH, Shilliam CS, Hughes ZA, Dawson LA, Gonzalez MI, Upton N, Pangalos MN, Dingwall C (2003) BACE1 (beta-secretase) transgenic and knockout mice: identification of neurochemical deficits and behavioral changes. Mol Cell Neurosci 24:646-655.

He W, Lu Y, Qahwash I, Hu XY, Chang A, Yan R (2004) Reticulon family members modulate BACE1 activity and amyloid-beta peptide generation. Nat Med 10:959-965.

He X, Chang WP, Koelsch G, Tang J (2002) Memapsin 2 (beta-secretase) cytosolic domain binds to the VHS domains of GGA1 and GGA2: implications on the endocytosis mechanism of memapsin 2. FEBS Lett 524:183-187.

He X, Zhu G, Koelsch G, Rodgers KK, Zhang XC, Tang J (2003) Biochemical and structural characterization of the interaction of memapsin 2 (betasecretase) cytosolic domain with the VHS domain of GGA proteins. Biochemistry 42:12174-12180.

He X, Li F, Chang WP, Tang J (2005) GGA proteins mediate the recycling pathway of memapsin 2 (BACE). J Biol Chem 280:11696-11703.

Holland KD, Kearney JA, Glauser TA, Buck G, Keddache M, Blankston JR, Glaaser IW, Kass RS, Meisler MH (2008) Mutation of sodium channel SCN3A in a patient with cryptogenic pediatric partial epilepsy. Neurosci Lett 433:65-70.

Hong L, Turner RT 3rd, Koelsch G, Shin D, Ghosh AK, Tang J (2002) Crystal structure of memapsin 2 (beta-secretase) in complex with an inhibitor OM00-3. Biochemistry 41:10963-10967.

Hu X, Hicks CW, He W, Wong P, Macklin WB, Trapp BD, Yan R (2006) Bacel modulates myelination in the central and peripheral nervous system. Nat Neurosci 9:1520-1525.

Hu X, Shi Q, Zhou X, He W, Yi H, Yin X, Gearing M, Levey A, Yan R (2007) Transgenic mice overexpressing reticulon 3 develop neuritic abnormalities. EMBO J 26:2755-2767.

Hu X, He W, Diaconu C, Tang X, Kidd GJ, Macklin WB, Trapp BD, Yan R (2008) Genetic deletion of BACE1 in mice affects remyelination of sciatic nerves. FASEB J 22:2970-2980.

Huse JT, Pijak DS, Leslie GJ, Lee VM, Doms RW (2000) Maturation and endosomal targeting of beta-site amyloid precursor protein-cleaving en- 
zyme. The Alzheimer's disease beta-secretase. J Biol Chem 275: 33729-33737.

Hussain I, Powell D, Howlett DR, Tew DG, Meek TD, Chapman C, Gloger IS, Murphy KE, Southan CD, Ryan DM, Smith TS, Simmons DL, Walsh FS, Dingwall C, Christie G (1999) Identification of a novel aspartic protease (Asp 2) as beta-secretase. Mol Cell Neurosci 14:419-427.

Hussain I, Hawkins J, Shikotra A, Riddell DR, Faller A, Dingwall C (2003) Characterization of the ectodomain shedding of the beta-site amyloid precursor protein-cleaving enzyme 1 (BACE1). J Biol Chem 278:3626436268.

Isom LL (2001) Sodium channel beta subunits: anything but auxiliary. Neuroscientist 7:42-54.

Kim DY, Ingano LA, Carey BW, Pettingell WH, Kovacs DM (2005) Presenilin/gamma-secretase-mediated cleavage of the voltage-gated sodium channel beta2-subunit regulates cell adhesion and migration. J Biol Chem 280:23251-23261.

Kim DY, Carey BW, Wang H, Ingano LA, Binshtok AM, Wertz MH, Pettingell WH, He P, Lee VM, Woolf CJ, Kovacs DM (2007) BACE1 regulates voltage-gated sodium channels and neuronal activity. Nat Cell Biol 9:755-764.

Kitazume S, Tachida Y, Oka R, Shirotani K, Saido TC, Hashimoto Y (2001) Alzheimer's beta-secretase, beta-site amyloid precursor protein-cleaving enzyme, is responsible for cleavage secretion of a Golgi-resident sialyltransferase. Proc Natl Acad Sci U S A 98:13554-13559.

Laird FM, Cai H, Savonenko AV, Farah MH, He K, Melnikova T, Wen H, Chiang HC, Xu G, Koliatsos VE, Borchelt DR, Price DL, Lee HK, Wong PC (2005) BACE1, a major determinant of selective vulnerability of the brain to amyloid- $\beta$ amyloidogenesis, is essential for cognitive, emotional, and synaptic functions. J Neurosci 25:11693-11709.

Lammich S, Schöbel S, Zimmer AK, Lichtenthaler SF, Haass C (2004) Expression of the Alzheimer protease BACE1 is suppressed via its 5'untranslated region. EMBO Rep 5:620-625.

Law AJ, Lipska BK, Weickert CS, Hyde TM, Straub RE, Hashimoto R, Harrison PJ, Kleinman JE, Weinberger DR (2006) Neuregulin 1 transcripts are differentially expressed in schizophrenia and regulated by $5^{\prime}$ SNPs associated with the disease. Proc Natl Acad Sci U S A 103:6747-6752.

Li Q, Südhof TC (2004) Cleavage of amyloid-beta precursor protein and amyloid-beta precursor-like protein by BACE 1. J Biol Chem 279:10542-10550.

Li R, Lindholm K, Yang LB, Yue X, Citron M, Yan R, Beach T, Sue L, Sabbagh M, Cai H, Wong P, Price D, Shen Y (2004) Amyloid beta peptide load is correlated with increased beta-secretase activity in sporadic Alzheimer's disease patients. Proc Natl Acad Sci U S A 101:3632-3637.

Li T, Wen H, Brayton C, Laird FM, Ma G, Peng S, Placanica L, Wu TC, Crain BJ, Price DL, Eberhart CG, Wong PC (2007) Moderate reduction of $\gamma$-secretase attenuates amyloid burden and limits mechanism-based liabilities. J Neurosci 27:10849-10859.

Lichtenthaler SF, Dominguez DI, Westmeyer GG, Reiss K, Haass C, Saftig P, De Strooper B, Seed B (2003) The cell adhesion protein P-selectin glycoprotein ligand-1 is a substrate for the aspartyl protease BACE1. J Biol Chem 278:48713-48719.

Lin X, Koelsch G, Wu S, Downs D, Dashti A, Tang J (2000) Human aspartic protease memapsin 2 cleaves the beta-secretase site of beta-amyloid precursor protein. Proc Natl Acad Sci U S A 97:1456-1460.

Lopez-Santiago LF, Pertin M, Morisod X, Chen C, Hong S, Wiley J, Decosterd I, Isom LL (2006) Sodium channel $\beta 2$ subunits regulate tetrodotoxinsensitive sodium channels in small dorsal root ganglion neurons and modulate the response to pain. J Neurosci 26:7984-7994.

Luo Y, Bolon B, Kahn S, Bennett BD, Babu-Khan S, Denis P, Fan W, Kha H, Zhang J, Gong Y, Martin L, Louis JC, Yan Q, Richards WG, Citron M, Vassar R (2001) Mice deficient in BACE1, the Alzheimer's betasecretase, have normal phenotype and abolished beta-amyloid generation. Nat Neurosci 4:231-232.

Luo Y, Bolon B, Damore MA, Fitzpatrick D, Liu H, Zhang J, Yan Q, Vassar R, Citron M (2003) BACE1 (beta-secretase) knockout mice do not acquire compensatory gene expression changes or develop neural lesions over time. Neurobiol Dis 14:81-88.

McConlogue L, Buttini M, Anderson JP, Brigham EF, Chen KS, Freedman SB, Games D, Johnson-Wood K, Lee M, Zeller M, Liu W, Motter R, Sinha S (2007) Partial reduction of BACE1 has dramatic effects on Alzheimer plaque and synaptic pathology in APP transgenic mice. J Biol Chem 282:26326-26334.
Meisler MH, Kearney JA (2005) Sodium channel mutations in epilepsy and other neurological disorders. J Clin Invest 115:2010-2017.

Michailov GV, Sereda MW, Brinkmann BG, Fischer TM, Haug B, Birchmeier C, Role L, Lai C, Schwab MH, Nave KA (2004) Axonal neuregulin-1 regulates myelin sheath thickness. Science 304:700-703.

Misra SN, Kahlig KM, George AL Jr (2008) Impaired NaV1.2 function and reduced cell surface expression in benign familial neonatal-infantile seizures. Epilepsia 49:1535-1545.

Murayama KS, Kametani F, Saito S, Kume H, Akiyama H, Araki W (2006) Reticulons RTN3 and RTN4-B/C interact with BACE1 and inhibit its ability to produce amyloid beta-protein. Eur J Neurosci 24:1237-1244.

O'Connor T, Sadleir KR, Maus E, Velliquette RA, Zhao J, Cole SL, Eimer WA, Hitt B, Bembinster LA, Lammich S, Lichtenthaler SF, Hébert SS, De Strooper B, Haass C, Bennett DA, Vassar R (2008) Phosphorylation of the translation initiation factor eIF2alpha increases BACE1 levels and promotes amyloidogenesis. Neuron 60:988-1009.

Ohno M, Sametsky EA, Younkin LH, Oakley H, Younkin SG, Citron M, Vassar R, Disterhoft JF (2004) BACE1 deficiency rescues memory deficits and cholinergic dysfunction in a mouse model of Alzheimer's disease. Neuron 41:27-33.

Ohno M, Cole SL, Yasvoina M, Zhao J, Citron M, Berry R, Disterhoft JF, Vassar R (2007) BACE1 gene deletion prevents neuron loss and memory deficits in 5XFAD APP/PS1 transgenic mice. Neurobiol Dis 26:134-145.

Pastorino L, Ikin AF, Lamprianou S, Vacaresse N, Revelli JP, Platt K, Paganetti P, Mathews PM, Harroch S, Buxbaum JD (2004) BACE (beta-secretase) modulates the processing of APLP2 in vivo. Mol Cell Neurosci 25: 642-649.

Qahwash I, He W, Tomasselli A, Kletzien RF, Yan R (2004) Processing amyloid precursor protein at the beta-site requires proper orientation to be accessed by BACE1. J Biol Chem 279:39010-39016.

Rajendran L, Schneider A, Schlechtingen G, Weidlich S, Ries J, Braxmeier T, Schwille P, Schulz JB, Schroeder C, Simons M, Jennings G, Knölker HJ, Simons K (2008) Efficient inhibition of the Alzheimer's disease betasecretase by membrane targeting. Science 320:520-523.

Roberds SL, Anderson J, Basi G, Bienkowski MJ, Branstetter DG, Chen KS, Freedman SB, Frigon NL, Games D, Hu K, Johnson-Wood K, Kappenman KE, Kawabe TT, Kola I, Kuehn R, Lee M, Liu W, Motter R, Nichols NF, Power M, et al. (2001) BACE knockout mice are healthy despite lacking the primary beta-secretase activity in brain: implications for Alzheimer's disease therapeutics. Hum Mol Genet 10:1317-1324.

Rockenstein E, Mante M, Alford M, Adame A, Crews L, Hashimoto M, Esposito L, Mucke L, Masliah E (2005) High beta-secretase activity elicits neurodegeneration in transgenic mice despite reductions in amyloidbeta levels: implications for the treatment of Alzheimer disease. J Biol Chem 280:32957-32967.

Savonenko AV, Melnikova T, Laird FM, Stewart KA, Price DL, Wong PC (2008) Alteration of BACE1-dependent NRG1/ErbB4 signaling and schizophrenia-like phenotypes in BACE1-null mice. Proc Natl Acad Sci U S A 105:5585-5590.

Scheffer IE, Harkin LA, Grinton BE, Dibbens LM, Turner SJ, Zielinski MA, Xu R, Jackson G, Adams J, Connellan M, Petrou S, Wellard RM, Briellmann RS, Wallace RH, Mulley JC, Berkovic SF (2007) Temporal lobe epilepsy and GEFS+ phenotypes associated with SCN1B mutations. Brain 130:100-109.

Schmidt JW, Catterall WA (1986) Biosynthesis and processing of the alpha subunit of the voltage-sensitive sodium channel in rat brain neurons. Cell 46:437-444.

Schröder M, Kaufman RJ (2006) Divergent roles of IRE1alpha and PERK in the unfolded protein response. Curr Mol Med 6:5-36.

Selkoe DJ (2008) Biochemistry and molecular biology of amyloid betaprotein and the mechanism of Alzheimer's disease. Handb Clin Neurol 89:245-260.

Shi Q, Prior M, He W, Tang X, Hu X, Yan R (2009) Reduced amyloid deposition in mice overexpressing RTN3 is adversely affected by preformed dystrophic neurites. J Neurosci 29:9163-9173.

Shi XP, Chen E, Yin KC, Na S, Garsky VM, Lai MT, Li YM, Platchek M, Register RB, Sardana MK, Tang MJ, Thiebeau J, Wood T, Shafer JA, Gardell SJ (2001) The pro domain of $\beta$-secretase does not confer strict zymogen-like properties but does assist proper folding of the protease domain. J Biol Chem 276:10366-10373.

Silvestri R (2009) Boom in the development of non-peptidic beta-secretase 
(BACE1) inhibitors for the treatment of Alzheimer's disease. Med Res Rev 29:295-338.

Singer O, Marr RA, Rockenstein E, Crews L, Coufal NG, Gage FH, Verma IM, Masliah E (2005) Targeting BACE1 with siRNAs ameliorates Alzheimer disease neuropathology in a transgenic model. Nat Neurosci 8:13431349.

Sinha S, Anderson JP, Barbour R, Basi GS, Caccavello R, Davis D, Doan M, Dovey HF, Frigon N, Hong J, Jacobson-Croak K, Jewett N, Keim P, Knops J, Lieberburg L, Power M, Tan H, Tatsuno G, Tung J, Schenk D, et al. (1999) Purification and cloning of amyloid precursor protein $\beta$-secretase from human brain. Nature 402:537-540.

Sisodia SS, St George-Hyslop PH (2002) gamma-Secretase, Notch, Abeta and Alzheimer's disease: where do the presenilins fit in? Nat Rev Neurosci 3:281-290.

Stefansson H, Sigurdsson E, Steinthorsdottir V, Bjornsdottir S, Sigmundsson T, Ghosh S, Brynjolfsson J, Gunnarsdottir S, Ivarsson O, Chou TT, Hjaltason $\mathrm{O}$, Birgisdottir B, Jonsson H, Gudnadottir VG, Gudmundsdottir E, Bjornsson A, Ingvarsson B, Ingason A, Sigfusson S, Hardardottir H, et al. (2002) Neuregulin 1 and susceptibility to schizophrenia. Am J Hum Genet 71:877-892.

Tamagno E, Bardini P, Obbili A, Vitali A, Borghi R, Zaccheo D, Pronzato MA, Danni O, Smith MA, Perry G, Tabaton M (2002) Oxidative stress increases expression and activity of BACE in NT2 neurons. Neurobiol Dis 10:279-288.

Tanzi RE, Bertram L (2005) Twenty years of the Alzheimer's disease amyloid hypothesis: a genetic perspective. Cell 120:545-555.

Tesco G, Koh YH, Kang EL, Cameron AN, Das S, Sena-Esteves M, Hiltunen M, Yang SH, Zhong Z, Shen Y, Simpkins JW, Tanzi RE (2007) Depletion of GGA3 stabilizes BACE and enhances beta-secretase activity. Neuron 54:721-737.

Tun H, Marlow L, Pinnix I, Kinsey R, Sambamurti K (2002) Lipid rafts play an important role in A beta biogenesis by regulating the beta-secretase pathway. J Mol Neurosci 19:31-35.

Vassar R, Bennett BD, Babu-Khan S, Kahn S, Mendiaz EA, Denis P, Teplow DB, Ross S, Amarante P, Loeloff R, Luo Y, Fisher S, Fuller J, Edenson S, Lile J, Jarosinski MA, Biere AL, Curran E, Burgess T, Louis JC, et al. (1999) Beta-Secretase cleavage of Alzheimer's amyloid precursor protein by the transmembrane aspartic protease BACE. Science 286:735-741.

Velliquette RA, O'Connor T, Vassar R (2005) Energy inhibition elevates $\beta$-secretase levels and activity and is potentially amyloidogenic in APP transgenic mice: possible early events in Alzheimer's disease pathogenesis. J Neurosci 25:10874-10883.

Vetrivel KS, Meckler X, Chen Y, Nguyen PD, Seidah NG, Vassar R, Wong PC, Fukata M, Kounnas MZ, Thinakaran G (2009) Alzheimer disease Abeta production in the absence of S-palmitoylation-dependent targeting of BACE1 to lipid rafts. J Biol Chem 284:3793-3803.

von Arnim CA, Tangredi MM, Peltan ID, Lee BM, Irizarry MC, Kinoshita A, Hyman BT (2004) Demonstration of BACE (beta-secretase) phosphorylation and its interaction with GGA1 in cells by fluorescence-lifetime imaging microscopy. J Cell Sci 117:5437-5445.

von Arnim CA, Kinoshita A, Peltan ID, Tangredi MM, Herl L, Lee BM, Spoelgen R, Hshieh TT, Ranganathan S, Battey FD, Liu CX, Bacskai BJ,
Sever S, Irizarry MC, Strickland DK, Hyman BT (2005) The low density lipoprotein receptor-related protein (LRP) is a novel beta-secretase (BACE1) substrate. J Biol Chem 280:17777-17785.

Wahle T, Prager K, Raffler N, Haass C, Famulok M, Walter J (2005) GGA proteins regulate retrograde transport of BACE1 from endosomes to the trans-Golgi network. Mol Cell Neurosci 29:453-461.

Wallace RH, Wang DW, Singh R, Scheffer IE, George AL Jr, Phillips HA, Saar K, Reis A, Johnson EW, Sutherland GR, Berkovic SF, Mulley JC (1998) Febrile seizures and generalized epilepsy associated with a mutation in the $\mathrm{Na}+$-channel betal subunit gene SCN1B. Nat Genet 19:366-370.

Walter J, Fluhrer R, Hartung B, Willem M, Kaether C, Capell A, Lammich S, Multhaup G, Haass C (2001) Phosphorylation regulates intracellular trafficking of $\beta$-secretase. J Biol Chem 276:14634-14641.

Wang H, Song L, Laird F, Wong PC, Lee HK (2008) BACE1 knock-outs display deficits in activity-dependent potentiation of synaptic transmission at mossy fiber to CA3 synapses in the hippocampus. J Neurosci 28:8677-8681.

Waxman SG (2007) Channel, neuronal and clinical function in sodium channelopathies: from genotype to phenotype. Nat Neurosci 10:405-409.

Wen Y, Onyewuchi O, Yang S, Liu R, Simpkins JW (2004) Increased betasecretase activity and expression in rats following transient cerebral ischemia. Brain Res 1009:1-8.

Willem M, Garratt AN, Novak B, Citron M, Kaufmann S, Rittger A, DeStrooper B, Saftig P, Birchmeier C, Haass C (2006) Control of peripheral nerve myelination by the beta-secretase BACE1. Science 314: 664-666.

Wong HK, Sakurai T, Oyama F, Kaneko K, Wada K, Miyazaki H, Kurosawa M, De Strooper B, Saftig P, Nukina N (2005) beta Subunits of voltagegated sodium channels are novel substrates of beta-site amyloid precursor protein-cleaving enzyme (BACE1) and gamma-secretase. J Biol Chem 280:23009-23017.

Yan R, Bienkowski MJ, Shuck ME, Miao H, Tory MC, Pauley AM, Brashier JR, Stratman NC, Mathews WR, Buhl AE, Carter DB, Tomasselli AG, Parodi LA, Heinrikson RL, Gurney ME (1999) Membrane-anchored aspartyl protease with Alzheimer's disease beta-secretase activity. Nature 402:533-537.

Yan R, Han P, Miao H, Greengard P, Xu H (2001) The transmembrane domain of the Alzheimer's beta-secretase (BACE1) determines its late Golgi localization and access to beta-amyloid precursor protein (APP) substrate. J Biol Chem 276:36788-36796.

Yang LB, Lindholm K, Yan R, Citron M, Xia W, Yang XL, Beach T, Sue L, Wong P, Price D, Li R, Shen Y (2003) Elevated beta-secretase expression and enzymatic activity detected in sporadic Alzheimer disease. Nat Med 9:3-4.

Yu FH, Westenbroek RE, Silos-Santiago I, McCormick KA, Lawson D, Ge P, Ferriera H, Lilly J, DiStefano PS, Catterall WA, Scheuer T, Curtis R (2003) Sodium channel $\beta 4$, a new disulfide-linked auxiliary subunit with similarity to $\beta 2$. J Neurosci 23:7577-7585.

Zhang X, Zhou K, Wang R, Cui J, Lipton SA, Liao FF, Xu H, Zhang YW (2007) Hypoxia-inducible factor lalpha (HIF-1alpha)-mediated hypoxia increases BACE1 expression and beta-amyloid generation. J Biol Chem 282:10873-10880. 